\title{
Thermodynamic Investigation of Titanium Hydride Formation from Reduction of Titanium (IV) Chloride with Magnesium Hydride in Presence of Hydrogen Atmosphere
}

\author{
Mohammad Rezaei Ardani ${ }^{1}$, Ahmad Fauzi Mohd Noor ${ }^{1}$, Sheikh Abdul Rezan Sheikh Abdul Hamid ${ }^{*}$, \\ Abdul Rahman Mohamed ${ }^{2}$, Hooi Ling Lee ${ }^{3}$, Ismail Ibrahim ${ }^{2}$ \\ ${ }^{1}$ School of Materials and Mineral Resources Engineering, Universiti Sains Malaysia, Nibong Tebal \\ 2 Mineral Research Centre, Mineral and Geoscience Department Malaysia, Ipoh, Perak \\ ${ }^{3}$ Nanomaterials Research Group, School of Chemical Sciences, Universiti Sains Malaysia, Penang, \\ Malaysia \\ 1* Corresponding author: srsheikh@usm.my
}

\begin{abstract}
$\underline{\text { Abstract }}$
Thermodynamic assessment and experimental investigation for formation of titanium hydride $\left(\mathrm{TiH}_{2}\right)$ from reduction of titanium tetrachloride $\left(\mathrm{TiCl}_{4}\right)$ with magnesium hydride $\left(\mathrm{MgH}_{2}\right)$ were carried out under hydrogen atmosphere. In this method, $\mathrm{TiH}_{2}$ production at low temperature was investigated, which can be used for further dehydrogenation process in titanium powder metallurgy. The effects of temperature, time, amount of titanium trifluoride $\left(\mathrm{TiF}_{3}\right)$ as catalyst, and ball milling time of $\mathrm{MgH}_{2}$ on reduction process were evaluated. The range of each parameters were set to $250-350^{\circ} \mathrm{C}$ for temperature, 2-4 $\mathrm{hr}$ for reaction time, $4-10 \mathrm{wt} \%$ for $\mathrm{TiF}_{3}$, and 1-2 $\mathrm{hr}$ for ball milling time. The phase transformations after reduction process were studied by X-ray diffraction (XRD) and energydispersive X-ray (EDX) analyziz. The morphology of powders was analyzed by scanning electron microscope (SEM). The results showed that titanium trichloride $\left(\mathrm{TiCl}_{3}\right)$ was formed as major product in experiments for the above conditions. However, with increasing the reaction time above 10hr, characterization study of the final products confirmed the formation of $\mathrm{TiH}_{2}$ as major product. Our
\end{abstract}


findings indicated that producing of $\mathrm{TiH}_{2}$ from reduction of $\mathrm{TiCl}_{4}$ with $\mathrm{MgH}_{2}$ at low temperature was feasible and could lead to low cost synthesis method for $\mathrm{TiH}_{2}$ for titanium powder production.

Keyword: Powder Metallurgy, Titanium, Titanium Hydride, Thermodynamic assessment

\section{$\underline{\text { Introduction }}$}

Titanium (Ti) and its alloys have been used in many industries such as aerospace, biomedical, power generation and structural applications due to properties such as low density, high temperature capabilities, high strength to density ratio, outstanding resistance to corrosion and high toughness in aggressive environment [1-4]. The demand to use $\mathrm{Ti}$ especially in aerospace industry is ever increasing nowadays; however, the high production costs of Ti is a major challenge [5], which makes the use of Ti restricted comparing to metals such as aluminum or steel [6].

The main problems in the industrial methods of Ti production with Kroll process and Hunter process [7], are the long processing time, high temperature and high energy consumption [8], which resulted in high cost of titanium in many industrial applications $[9,10]$. Several researchers [11-17] tried to develop new methods to produce titanium powder with powder metallurgy techniques in order to lower the production costs. Some of these processes such as hydrogen assisted magnesiothermic reduction (HAMR) and direct reduction of Ti-slag (DRTS) are using $\mathrm{TiO}_{2}$ as a precursor [11-13]; however, the base material in $\mathrm{TiRO}^{\mathrm{TM}}$ and Armstrong processes to produce Ti metal is $\mathrm{TiCl}_{4}$ [14-17].

Whereas, reduction of chlorine content in $\mathrm{TiCl}_{4}$ is more convenient comparing to remove oxygen from $\mathrm{TiO}_{2}$, the Ti powder from $\mathrm{TiCl}_{4}$ precursor is more pure considering the oxygen content. Besides, the chlorine by-products such as $\mathrm{TiCl}_{3}$ can participate in the production process, while the oxide composition in processes using $\mathrm{TiO}_{2}$ can make the process more complicated by formation of high melting point oxides $[12,16]$. On the other hand, $\mathrm{TiCl}_{4}$ is considerably corrosive and volatile gas. In addition, the nature of processes which use $\mathrm{TiCl}_{4}$ is liquid to solid process and the morphology and particle size control are very challenging in this condition [16]. As a result the authors proposed an optimized method to improve the Kroll process via low temperature chlorination [18-19] and electrochemical reduction via $\mathrm{TiS}_{2}$ [20] and use the obtained $\mathrm{TiCl}_{4}$ as precursor to produce $\mathrm{TiH}_{2}$ powder from the reduction process with metal hydrides at lower temperature with gas-solid reaction [21-23]. Hydrogen can then be easily removed from $\mathrm{TiH}_{2}$ through a simple heat treatment in vacuum or inert atmosphere, thereby leaving pure $\mathrm{Ti}$ with extremely low levels of oxygen and hydrogen. $\mathrm{TiH}_{2}$ is insoluble in water, resistant to dilute acid solutions, and has minimal or no solubility for other impurities [24]. 
Previous studies [25-27] investigated the magnesium-hydrogen reduction process of $\mathrm{TiCl}_{4}$ to produce $\mathrm{TiH}_{2}$ at $800-850{ }^{\circ} \mathrm{C}$. The use of hydrogen gas in the process has several advantages such as decreases in reduction time, increases in the efficiency of magnesium usage and reduce further vacuum distillation stage time and temperature [28]. However, the elevated temperature of reduction step is still affecting the titanium production costs. The authors' proposed method [21-23] was carried out at lower temperature range in order to produce low cost titanium powder. In this study the $\mathrm{TiCl}_{4}$ is reduced to $\mathrm{TiH}_{2}$ with ball milled $\mathrm{MgH}_{2}$ under hydrogen atmosphere at temperature range 250 $350^{\circ} \mathrm{C}$. The feasibility of this method is based on several fundamental principles which are discussed in details as follow.

\section{Experimental}

The $\mathrm{TiCl}_{4}$ and $\mathrm{MgH}_{2}$ is expected to react as Eq. 1 to produce $\mathrm{TiH}_{2}$. The calculation for the amount of standard Gibbs free energy change $\left(\Delta \mathrm{G}^{\circ}\right)$ for Eq. 1 between $250-350^{\circ} \mathrm{C}$ shows negative value which indicates the reaction is thermodynamically feasible.

$$
\begin{gathered}
\mathrm{TiCl}_{4}(\mathrm{~g})+2 \mathrm{MgH}_{2}=\mathrm{TiH} 2+2 \mathrm{MgCl}_{2}+\mathrm{H}_{2}(\mathrm{~g}) \quad \Delta G^{0}=-488.420- \\
0.0393 \mathrm{~T}(\mathrm{~kJ} / \mathrm{mol}) \text { (1) }
\end{gathered}
$$

The schematic of experimental setup to perform the reaction between $\mathrm{MgH}_{2}$ and $\mathrm{TiCl}_{4}$ is illustrated in Fig. 1. Phosphorous pentoxide $\left(\mathrm{P}_{2} \mathrm{O}_{5}\right)$ was used to absorb any moisture in the $\mathrm{H}_{2}$ gas before entering the system. The flow rate of $\mathrm{H}_{2}$ gas was monitored and controlled regularly during the experiment. Gaseous $\mathrm{TiCl}_{4}$ and $\mathrm{H}_{2}$ gas was passed through the quartz tube in the furnace. $\mathrm{MgH}_{2}$ powder was ball milled under $\mathrm{Ar}$ gas with $\mathrm{TiF}_{3}$ as catalyst to lower the dehydrogenation temperature of $\mathrm{MgH}_{2}$ while increasing the surface area of the powder. Three different weight ratios between $\mathrm{MgH}_{2}$ and $\mathrm{TiF}_{3}$ were used including $4-10 \mathrm{wt} \%$ of $\mathrm{MgH}_{2}$ based on previous study [29]. The weight of $\mathrm{MgH}_{2}$ with catalyst sample was constant at $1 \mathrm{~g}$. The milled powder was placed in a crucible at the center of the quartz tube at specified temperature. Residual exit gas from the tube was absorb with the hydrochloric acid $(\mathrm{HCl})$ and neutralized by $\mathrm{NaOH}$ before excess gas was released to the atmosphere [22].

The experiments were carried out by varying four main factors with three distinct levels which are introduced as Table 1. Temperature was set to 250,300 and $350^{\circ} \mathrm{C}$, reaction time 120,180 and 240 minutes, the amount of catalyst 4, 7 and $10 \mathrm{wt} \%$, and the ball milling time 60, 90 and 120 minutes. All reduced samples were kept in inert atmosphere under Mylar film sandwich [30]. The phase compositions and morphology of the reaction products as well as the extent of reduction process were studied by $\mathrm{X}$-ray Diffraction analysis using $\mathrm{Cu}-\mathrm{K} \alpha$ radiation with the wavelength of $\lambda=1.5404 \AA$ (XRD; Bruker D8-advance, USA). The surface morphology and the elemental 
composition of the reaction product were studied by Scanning Electron Microscopy equipped with Electron Dispersive X-ray Spectroscopy (SEM/EDX; Tescan MIRA3, Czech Republic and ZEISS SUPRA 35VP, Germany).

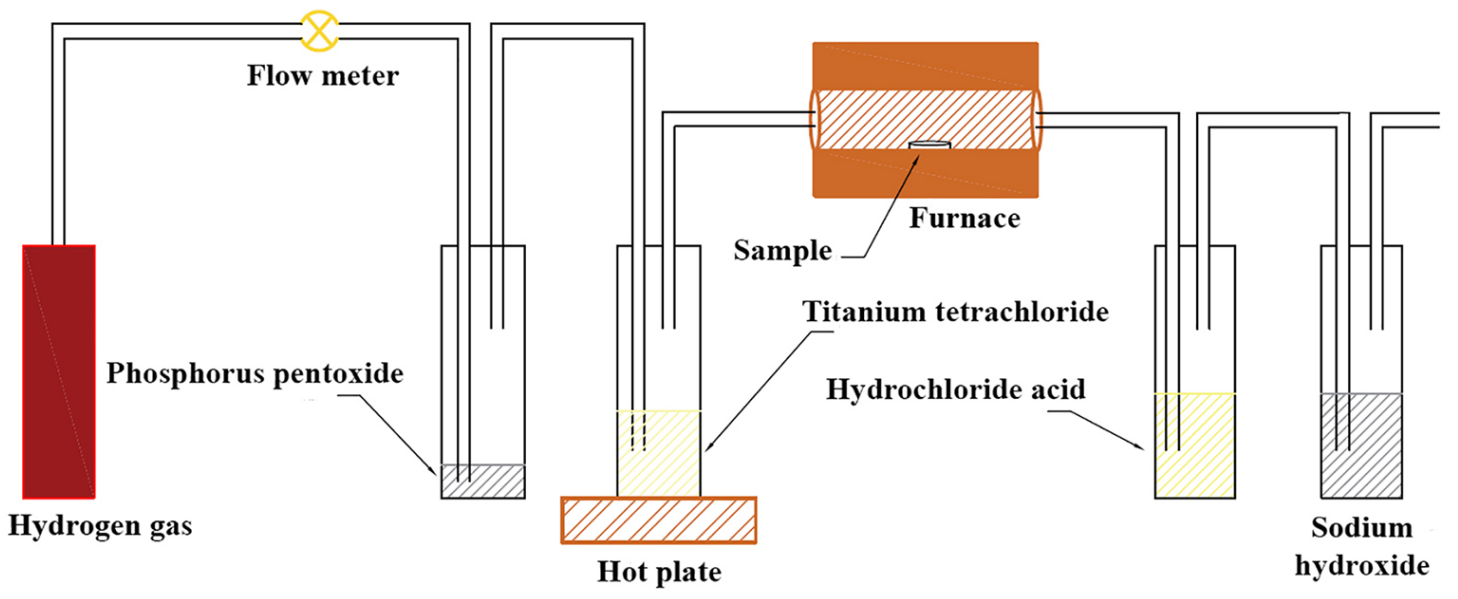

Fig. 1. Experimental Set-up. From the left to right: $\mathrm{H}_{2}$ gas passed through the $\mathrm{P}_{2} \mathrm{O}_{5}$ till $\mathrm{TiCl}_{4}$ scrubber.

Table 1. Experimental matrix: Factors and levels

\section{$\begin{array}{lllll}\text { Run } & \text { Factor } 1 & \text { Factor } 2 & \text { Factor } 3 & \text { Factor } 4\end{array}$}

\begin{tabular}{|c|c|c|c|c|}
\hline A:Temperature & B:Time & $\begin{array}{c}\text { C:Catalyst } \\
\text { Amount }\end{array}$ & $\begin{array}{c}\text { D:Ball } \\
\text { Milling } \\
\text { Time }\end{array}$ & $\begin{array}{c}\mathrm{TiCl}_{3} \\
\text { amount }\end{array}$ \\
\hline
\end{tabular}

${ }^{\circ} \mathrm{C} \quad$ Min $\quad$ \%wt $\quad$ Min $\quad(g) \quad$ (g)

$\begin{array}{lllllll}1 & 250 & 120 & 4 & 60 & 0.27 & 1.76\end{array}$




\begin{tabular}{|c|c|c|c|c|c|c|}
\hline 2 & 250 & 120 & 10 & 60 & 0.13 & 1.67 \\
\hline 3 & 350 & 240 & 10 & 60 & 0.29 & 2.36 \\
\hline 4 & 250 & 120 & 4 & 120 & 0.13 & 1.75 \\
\hline 5 & 250 & 240 & 10 & 120 & 0.20 & 1.71 \\
\hline 6 & 350 & 240 & 4 & 60 & 0.44 & 2.52 \\
\hline 7 & 300 & 180 & 7 & 90 & 0.47 & 2.43 \\
\hline 8 & 250 & 240 & 4 & 120 & 0.10 & 1.76 \\
\hline 9 & 350 & 120 & 4 & 120 & 0.16 & 2.66 \\
\hline 10 & 350 & 120 & 10 & 120 & 0.18 & 2.35 \\
\hline 11 & 350 & 120 & 10 & 60 & 0.43 & 2.55 \\
\hline 12 & 250 & 240 & 10 & 60 & 0.15 & 1.76 \\
\hline 13 & 250 & 120 & 10 & 120 & 0.13 & 1.72 \\
\hline 14 & 300 & 180 & 7 & 90 & 0.66 & 2.59 \\
\hline 15 & 350 & 240 & 10 & 120 & 0.53 & 2.67 \\
\hline
\end{tabular}


16

300

180

350

350

240

120

4

60

0.10

18

19

\section{$\underline{\text { Results and Discussion }}$}

\section{Thermodynamic calculations}

In order to evaluate the effect of temperature, partial pressure of $\mathrm{H}_{2}$ and $\mathrm{Cl}_{2}$ gas was calculated over Ti-Cl-H predominance diagram in Fig. 2 at a fixed partial pressure of $P_{\mathrm{Cl}_{2}}=1 \times 10^{-30}$ atm and $P_{\mathrm{Cl}_{2}}=1 \times 10^{-35}$ atm. Fig. 2(a) shows that $\mathrm{Ti}, \mathrm{Cl}$ and $\mathrm{H}$ were stable phases as $\mathrm{TiCl}_{3}, \mathrm{TiCl}_{2}$ and $\mathrm{TiH}_{2}$ when the $\mathrm{H}_{2}$ pressure of 1 atm and the temperature ranged between $250-350^{\circ} \mathrm{C}$. Fig. 2(b) indicates that with the decrease in $P_{\mathrm{Cl}_{2}}$ the $\mathrm{TiH}_{2}$ stability area will extend to lower temperatures and it was stable phase. This particular distinction between the two diagrams represents an important factor over the experimental conditions necessary to obtain $\mathrm{TiH}_{2}$, which is $P_{\mathrm{Cl}_{2}}$ should be low enough. $\mathrm{TiCl}_{3}$ can be produced from the reaction between $\mathrm{TiCl}_{4}$ and $\mathrm{MgH}_{2}$ as Eq. 2 .

$$
\begin{gathered}
2 \mathrm{TiCl}_{4}(\mathrm{~g})+\underset{\mathrm{MgH}}{2}=2 \mathrm{TiCl}_{3}+\mathrm{MgCl}_{2}+\mathrm{H}_{2}(\mathrm{~g}) \quad \Delta G^{0}= \\
-415.140+0.197 \mathrm{~T}(\mathrm{~kJ} / \mathrm{mol})
\end{gathered}
$$

Although Eq. 1 is thermodynamically feasible, to maintain $\mathrm{TiH}_{2}$ formation, $\mathrm{TiCl}_{3}$ is only stable at temperature above $350{ }^{\circ} \mathrm{C}$ for $P_{\mathrm{H}_{2}}$ of 1 atm and $P_{\mathrm{Cl}_{2}}$ below $1 \times 10^{-30}$ atm. In contrast, Fig. 2(b) demonstrates that at lower $P_{\mathrm{Cl}_{2}}, \mathrm{TiH}_{2}$ was stable phase above $250^{\circ} \mathrm{C}$. Moreover, with increasing $P_{H_{2}}$ to $10 \mathrm{~atm}, \mathrm{TiH}_{2}$ was predominant even at lower temperatures. With the presence of $\mathrm{H}_{2}$ around $1 \mathrm{~atm}$ was critical to have $\mathrm{TiH}_{2}$ at lower temperatures. This is the main reason why there was a need to carry out the reduction process in the presence of $\mathrm{H}_{2}$ atmosphere instead of inert atmosphere like previous studies $[22,23]$ to facilitate the reduction process. 

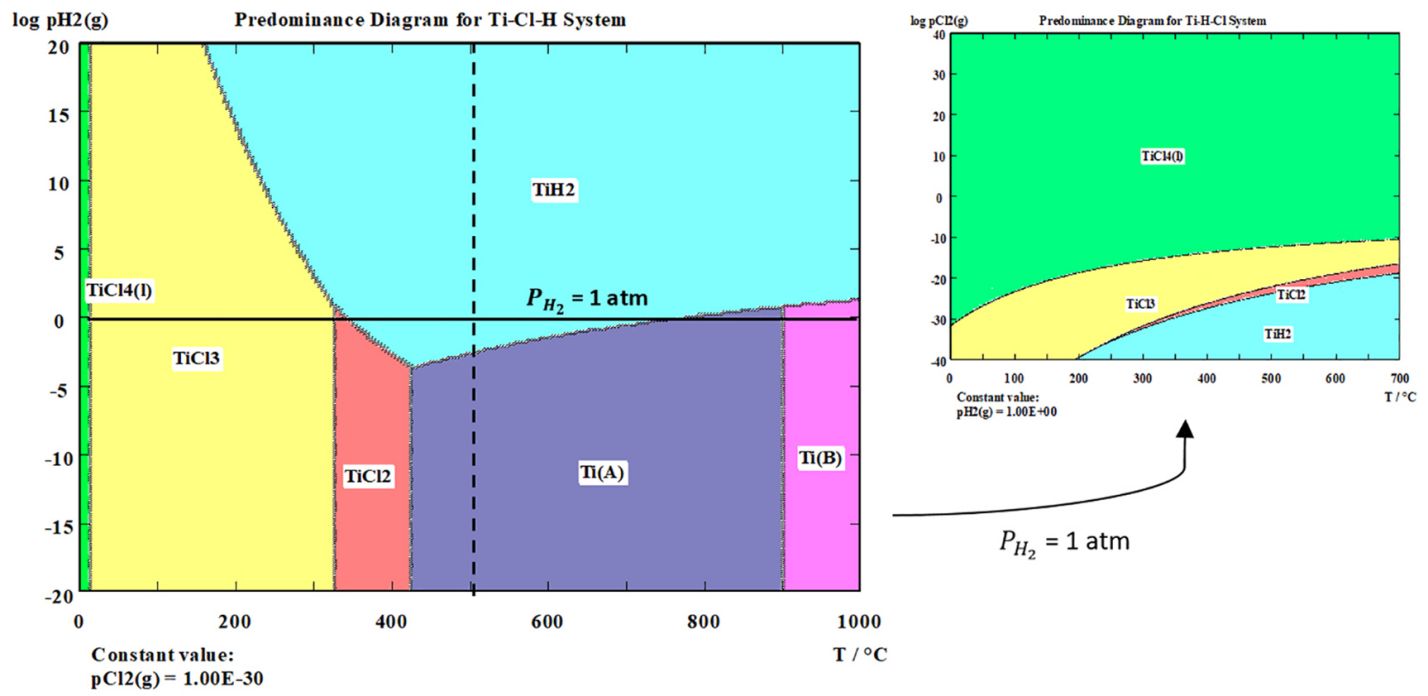

(a)
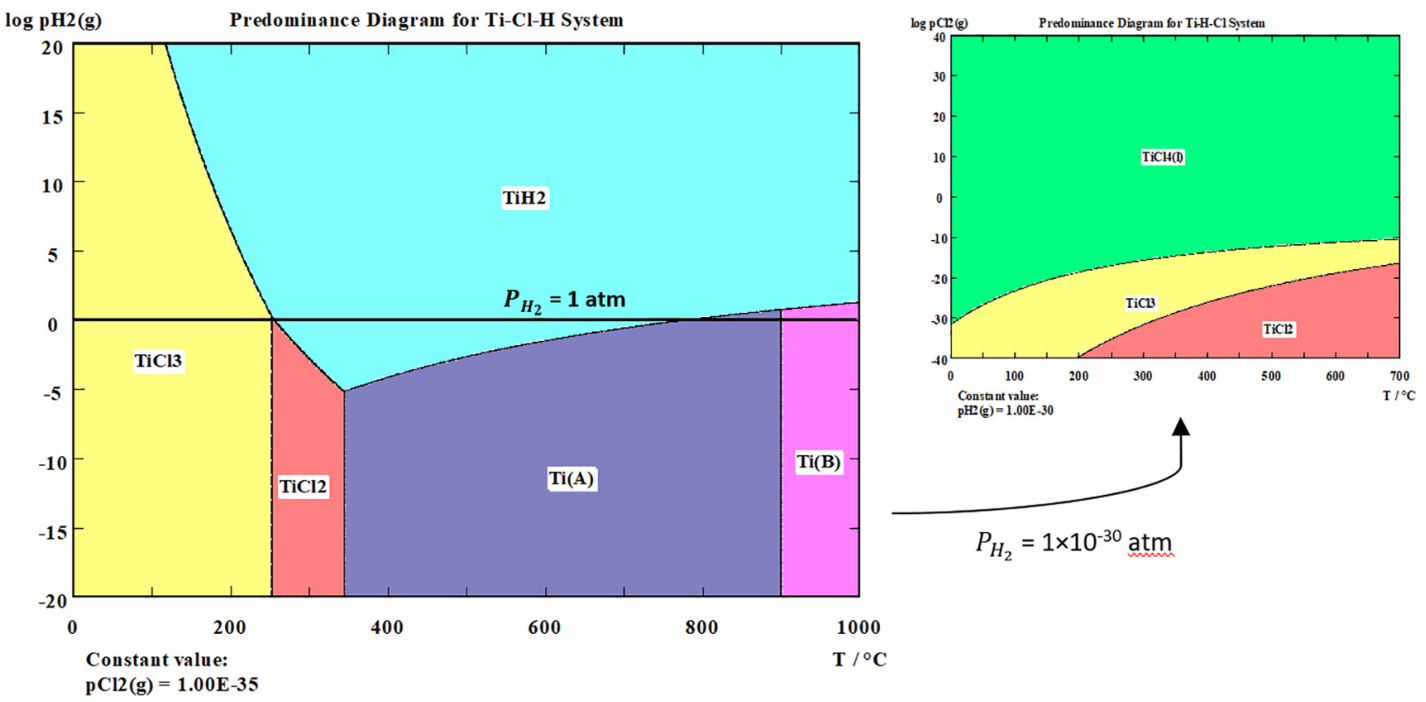

(b)

Fig. 2. Predominance Diagram for Ti-Cl-H system at a constant partial pressure of $\mathbf{C l}_{2}$ (a) $P_{\mathrm{Cl}_{2}}=\mathbf{1} \times \mathbf{1 0} 0^{-30}$ atm and (b) $P_{C_{2}=1 \times 10^{-35}}$ atm 
Gibbs minimization diagrams were developed to study the possible phase formation with the change in molar ratio of $\mathrm{TiCl}_{4}: \mathrm{MgH}_{2}$. Based on experimental conditions, the $\mathrm{MgH}_{2}$ amount was set at $90 \%$ of the input materials with $10 \%$ of $\mathrm{TiF}_{3}$ as catalyst in the calculations. Also, the constant amount of $\mathrm{H}_{2}$ equivalent to $2 \mathrm{kmol}$ was considered in the calculations. The main reason for these calculations was to consider the varying amount of $\mathrm{TiCl}_{4}$ over time during the reduction process. Therefore, different reaction times caused different components to be reacted. The HSC Chemistry software v6.0 (Outokumpu Research Oy, Finland) with Gibbs energy minimization method was applied to analyze the possible equilibrium phase compositions during the reactions [31]. The main reaction to synthesize $\mathrm{TiH}_{2}$ from $\mathrm{TiCl}_{4}$ was given in Eq. 1. On the other hand, Eq. 3 and 4 indicate that $\mathrm{TiCl}_{3}$ was a more favourable route than $\mathrm{TiCl}_{4}$ to react with $\mathrm{MgH}_{2}$ due to its lower $\Delta \mathrm{G}^{\circ}$ compared with Eq. 1. However, one of the important challenges in this process was the proper molar ratio of reactants. In the presence of excess $\mathrm{TiCl}_{4}$, there was a possibility that the produced $\mathrm{TiH}_{2}$ may react with $\mathrm{TiCl}_{4}$ to form $\mathrm{TiCl}_{3}$ as Eq. 5.

$$
\begin{aligned}
& 2 \mathrm{TiCl}_{4}(\mathrm{~g})+2 \mathrm{H}_{2}(\mathrm{~g})=2 \mathrm{TiCl} 3+2 \mathrm{HCl}(\mathrm{g}) \quad \Delta G^{0}=-96.820+ \\
& 0.170 T(k J / m o) \quad(3) \\
& 2 \mathrm{TiCl}_{3}+3 \mathrm{MgH}_{2}=2 \mathrm{TiH}_{2}+3 \mathrm{MgCl}_{2}+\mathrm{H}_{2}(\mathrm{~g}) \quad \Delta G^{0}=-575.980- \\
& 0.0679 T(k J / m o) \quad(4) \\
& 5 \mathrm{TiCl}_{4}(\mathrm{~g})+\mathrm{TiH}_{2}=6 \mathrm{TiCl} 3+2 \mathrm{HCl}(\mathrm{g}) \quad \Delta G^{0}=-524.460+ \\
& 0.510 T(k J / m o) \quad(5)
\end{aligned}
$$

The stoichiometric molar ratio for the $\mathrm{TiCl}_{4}$ to $\mathrm{MgH}_{2}$ was 1:2 according to Eq. 1. Fig. 3 indicates the equilibrium phase composition for the stoichiometric condition. Totally, the major products were $\mathrm{TiH}_{2}, \mathrm{MgCl}_{2}$ and $\mathrm{H}_{2}$ according to Eq. 1. It is to be noted, the presence of $\mathrm{MgF}_{2}$ in the final composition, is related to the reaction between $\mathrm{TiF}_{3}$ and $\mathrm{MgH}_{2}$ to produce $\mathrm{MgF}_{2}$ and $\mathrm{TiH}_{2}$ [32], which was almost negligible. 


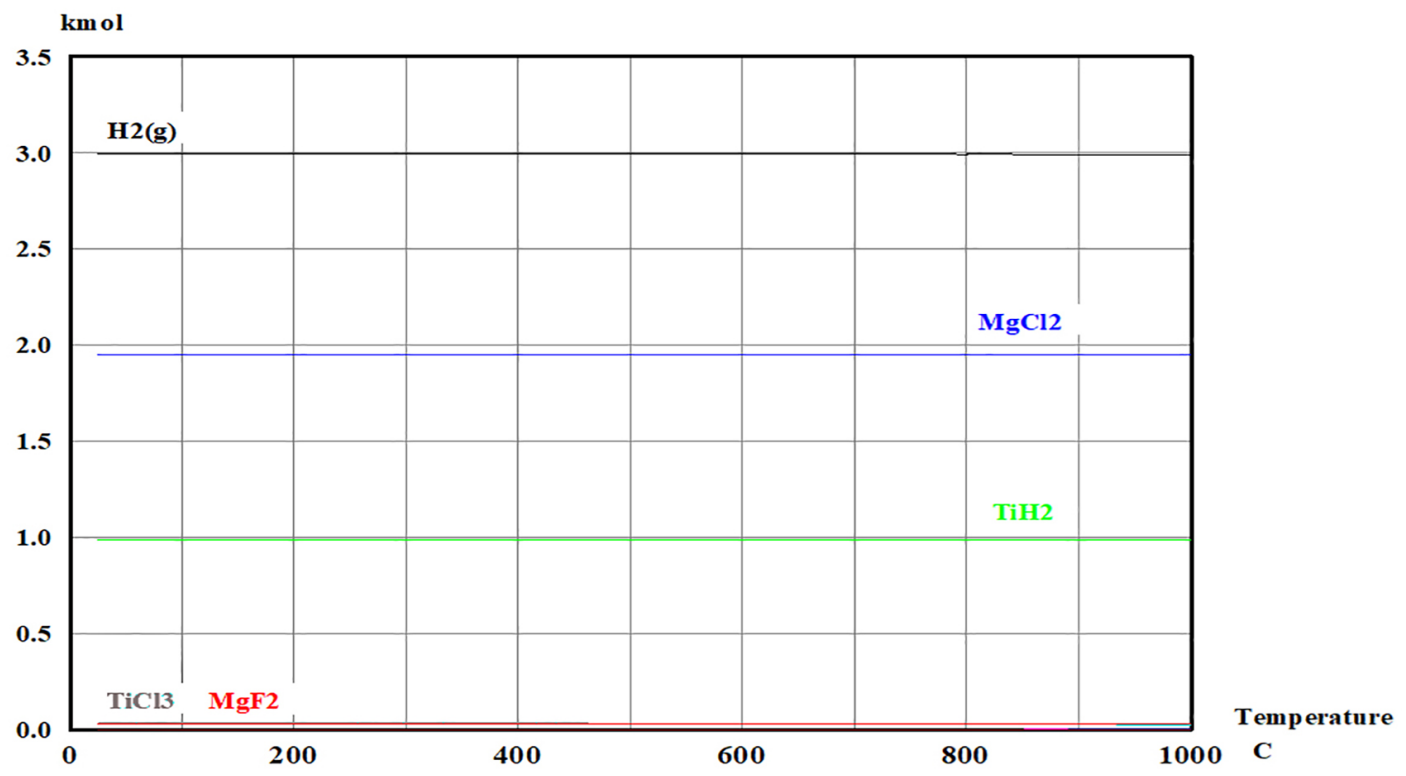

Fig. 3: Theoretical equilibrium phase composition calculated for the stoichiometric ration of $\mathrm{TiCl}_{4}: \mathrm{MgH}_{2}$ $:=1: 2$ and $H_{2}$ at 1 kmole.

The predicted phases with the increase in molar ratios of $\mathrm{TiCl}_{4}$ to $\mathrm{MgH}_{2}$ to $3: 1$ were represented in Fig. 4. As calculated, with an increase in molar ratio of reactants, the $\mathrm{TiCl}_{3}$ phase formed rather than $\mathrm{TiH}_{2}$. As expected, $\mathrm{TiH}_{2}$ and $\mathrm{MgCl}_{2}$ were formed at lower temperatures. However, the $\Delta \mathrm{G}^{\circ}$ for the reaction of Eq. 6 was more negative than Eq. 3 above $200^{\circ} \mathrm{C}$ and the reaction will proceed to produce $\mathrm{H}_{2}$ and $\mathrm{TiCl}_{4}$. In addition, the produced $\mathrm{TiH}_{2}$ can react via Eq. 5 and there was no $\mathrm{TiH}_{2}$ formed calculated in the equilibrium composition diagram. In essence, the main reaction between $\mathrm{TiCl}_{4}$ and $\mathrm{MgH}_{2}$ via Eq. 2 was occurring only. Nevertheless, the formation of $\mathrm{TiH}_{2}$ was possible through reaction between $\mathrm{MgH}_{2}$ and $\mathrm{TiCl}_{4}$; however, the molar ratio of reactants was critically important to ensure $\mathrm{TiH}_{2}$ formed.

$$
\underset{0.159 \mathrm{~T}(\mathrm{~kJ} / \mathrm{mo})}{2 \mathrm{TiCl}_{3}}+\underset{(5)}{2 \mathrm{HCl}(\mathrm{g})}=2 \mathrm{TiCl}(\mathrm{g})+\mathrm{H}_{2}(\mathrm{~g}) \quad \Delta G^{0}=47.97-
$$




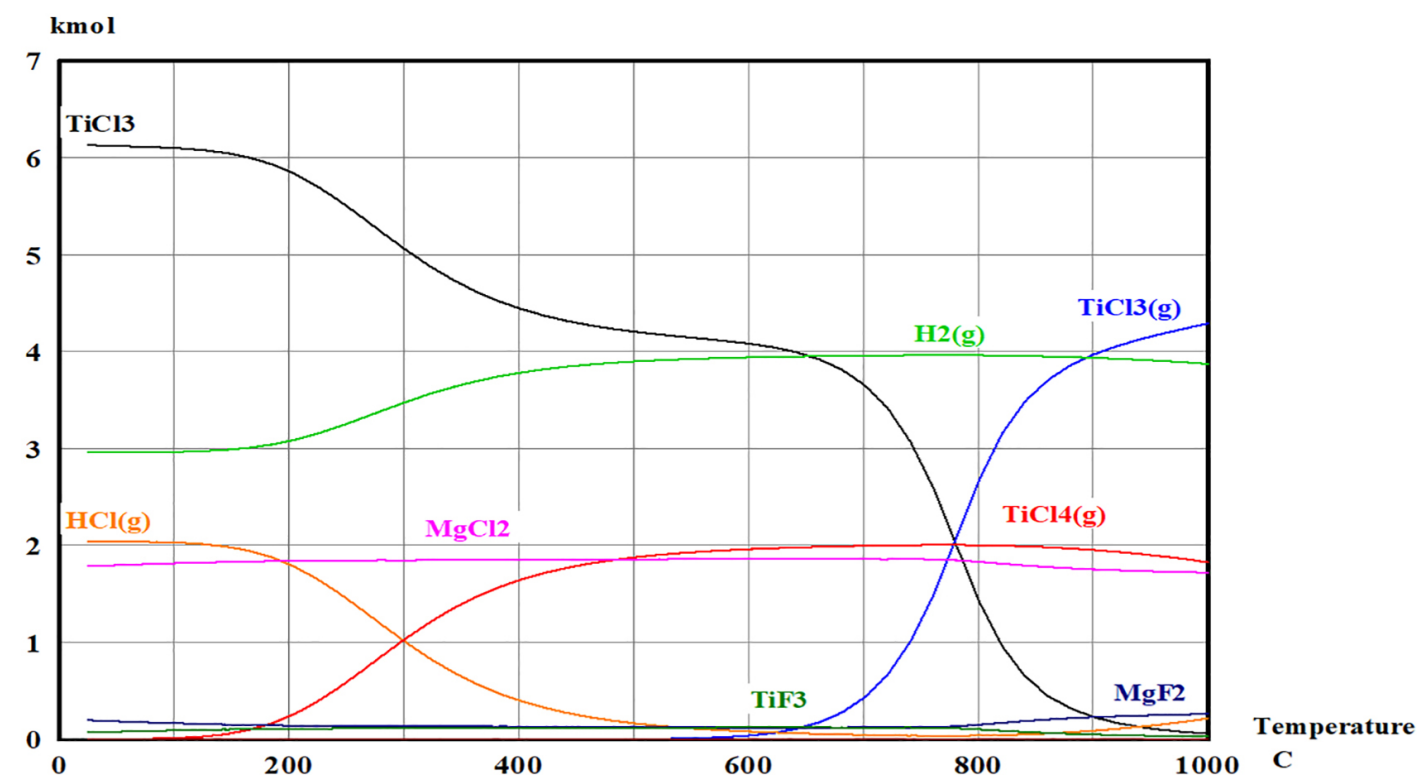

Fig. 4: Theoretical equilibrium phase composition calculated for $\mathrm{TiCl}_{4}: \mathrm{MgH}_{2}: \mathrm{H}_{2}=6: 2: 2$

In regard to the decreasing of temperature range to formed $\mathrm{TiH}_{2}$, the thermodynamics results indicate with increase in $P_{H_{2}}$ or decrease in $P_{\mathrm{Cl}_{2}}$ in the system, $\mathrm{TiH}_{2}$ was the predominant phase. Based on the thermodynamic evaluation, it was clear that reduction of $\mathrm{TiCl}_{4}$ with $\mathrm{MgH}_{2}$ in $\mathrm{H}_{2}$ atmosphere was feasible to form selectively $\mathrm{TiH}_{2}$ within a particular temperature range, as demonstrated through the Gibbs minimization calculations.

\section{Phase transformation}

Regarding the phase transformations during $\mathrm{MgH}_{2}$ reduction of $\mathrm{TiCl}_{4}$, the thermodynamic calculation shows that the formation of equilibrium phases is highly dependent on the molar ratio of reactants. In this study, the final products after reduction process were analyzed by XRD to determine the phases. Despite the results from thermodynamic assessment, which shows that final equilibrium phases should be $\mathrm{MgCl}_{2}, \mathrm{TiH}_{2}$ and $\mathrm{TiCl}_{3}$, the XRD results showed that the actual reaction products were mainly $\mathrm{MgCl}_{2}$ and $\mathrm{TiCl}_{3}$. In this case, the final products significantly affected by the factors including molar ratio of $\mathrm{TiCl}_{4}: \mathrm{MgH}_{2}$, temperature, time, and the $P_{H_{2}}$ which can influence the reactions kinetics [33]. Furthermore, the $\mathrm{TiCl}_{4}$ gas was carried into the furnace with $\mathrm{H}_{2}$ and there was no actual data about the real ratio of $\mathrm{TiCl}_{4}: \mathrm{H}_{2}$ gas in the furnace during the reaction in the literature. According to Fig. 5. XRD 
results show that the main phases was $\mathrm{TiCl}_{3}$ and $\mathrm{MgCl}_{2}$ or $\mathrm{MgCl}_{2} \cdot\left(\mathrm{H}_{2} \mathrm{O}\right)_{\mathrm{X}}$. Although the samples were kept in Mylar film, however for the XRD analysis the samples were removed from Mylar which then can be absorbed moisture as $\mathrm{MgCl}_{2}$ is very hygroscopic according to Eq. 7 and 8 [34, 35].

$$
\begin{aligned}
& \mathrm{MgCl}_{2} \cdot 4 \mathrm{H}_{2} \mathrm{O}+2 \mathrm{H}_{2} \mathrm{O}(\mathrm{g})=\mathrm{MgCl}_{2} \cdot 6 \mathrm{H}_{2} \mathrm{O} \quad \Delta G_{0}^{f}=-2113.50(\mathrm{~kJ} / \mathrm{mol}) \text { at } \mathrm{T}= \\
& 298.15 \mathrm{~K}(7) \\
& \mathrm{MgCl}_{2} \cdot 2 \mathrm{H}_{2} \mathrm{O}+2 \mathrm{H}_{2} \mathrm{O}(\mathrm{g})=\mathrm{MgCl}_{2} \cdot 4 \mathrm{H}_{2} \mathrm{O} \quad \Delta G_{0}^{f}=-1623.77(\mathrm{~kJ} / \mathrm{mol}) \text { at } \mathrm{T}= \\
& 298.15 \mathrm{~K} \text { (8) }
\end{aligned}
$$

In addition, the presence of $\mathrm{MgH}_{2}$ in the $\mathrm{XRD}$ results at $\mathrm{T}=250^{\circ} \mathrm{C}$, shows that the reaction time was inadequate. The amount of $\mathrm{TiCl}_{3}$ phase in the final powder were calculated based on the Rietveld analysis. According to table 1, it can be concluded with the increase in the temperature from 250 to $350^{\circ} \mathrm{C}$ more $\mathrm{TiCl}_{3}$ were formed. Also, the final powder weight showed that with the increase in temperature and reaction time, more $\mathrm{TiCl}_{4}$ were reacted.

As it was mentioned, previous studies [29, 32] reported that the mechanical milling of $\mathrm{MgH}_{2}$ with $\mathrm{TiF}_{3}$ as the catalyst can reduced the dehydrogenation temperature. The higher the amount of catalyst amount and ball milling time resulted in the decrease in dehydrogenation temperature of $\mathrm{MgH}_{2}$. The comparison between the XRD data indicated that with the increase in temperature from $250^{\circ} \mathrm{C}$ to $350^{\circ} \mathrm{C}$, the intensity of $\mathrm{MgH}_{2}$ peaks were weaker which represented the increase in $\mathrm{MgH}_{2}$ reaction with $\mathrm{TiCl}_{4}$. Also, the presence of $\mathrm{Mg}$ peaks at $350^{\circ} \mathrm{C}$ confirmed the dehydrogenation of $\mathrm{MgH}_{2}$ at this temperature. The $\mathrm{Mg}$ content at $350^{\circ} \mathrm{C}$ was also included in the amount of unreacted $\mathrm{MgH}_{2}$ on the XRD patterns in Fig. 5. It should be pointed that dehydrogenation of $\mathrm{MgH}_{2}$ during the reduction process increases the $P_{H_{2}}$ in the system, which have the positive effect on the formation of $\mathrm{TiH}_{2}$ according to Fig. 2. The unstable $\mathrm{TiH}$ phase was only observed as low intensity peaks in the experiments at $350^{\circ} \mathrm{C}$ and $4 \mathrm{hrs}$, such as run $\# 18$ according to Fig. 5. The low TiH was attributed to the reactants molar ratio and the formation kinetics of $\mathrm{TiH}_{2}$ [33]. Moreover, the predominance diagrams of Ti-Cl-H indicates that the change in the $P_{\mathrm{Cl}_{2}}$ can be resulted in different stability area for $\mathrm{TiCl}_{3}$ and $\mathrm{TiH}_{2}$ at the temperature range of $250-350^{\circ} \mathrm{C}$.

The XRD analyziz showed that with the increase in the reaction time and temperature the titanium hydride formation is observed. Given this, three different experiments were carried out for the 8, 10 and $12 \mathrm{hrs}$. These experiments had two distinct differences. Based on the thermodynamic assessment from Fig. 2(a), temperature was set to $400^{\circ} \mathrm{C}$ to ensure the stability of $\mathrm{TiH}_{2}$. In addition, the constant stoichiometry amount of $\mathrm{TiCl}_{4}$ was added to the $\mathrm{MgH}_{2}$ in crucible in the furnace to avoid the increasing in the ratio of the $\mathrm{TiCl}_{4}: \mathrm{MgH}_{2}$. The $\mathrm{MgH}_{2}$ was milled for 60 min with $10 \%$ wt of $\mathrm{TiF}_{3}$. The XRD results is shown in Fig. 6. As it can be seen, with the increase in reaction time to $8 \mathrm{hrs}$ the TiH 
and $\mathrm{TiH}_{2}$ phases were starting to form. Above $10 \mathrm{hrs}$ the intensity of the $\mathrm{TiH}_{2}$ and $\mathrm{TiH}$ phases is increased. Another interesting point of the XRD results is that there was no sign of $\mathrm{TiCl}_{3}$ which shows in this conditions the $\mathrm{TiCl}_{3}$ was also reacted to produce titanium hydride.

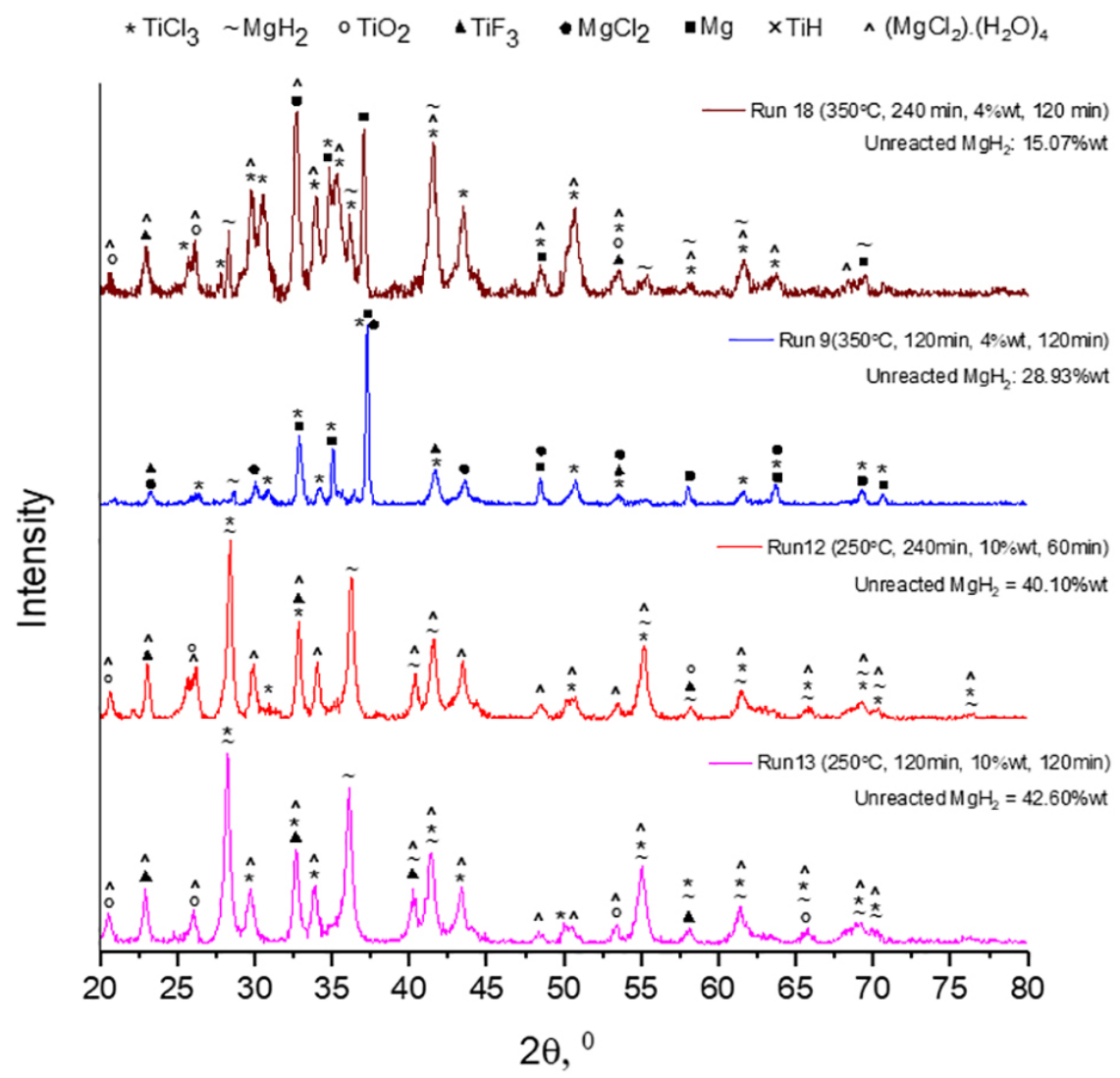

Fig. 5. XRD analysis data for the runs \#9, \#12, \#13 and \#18 


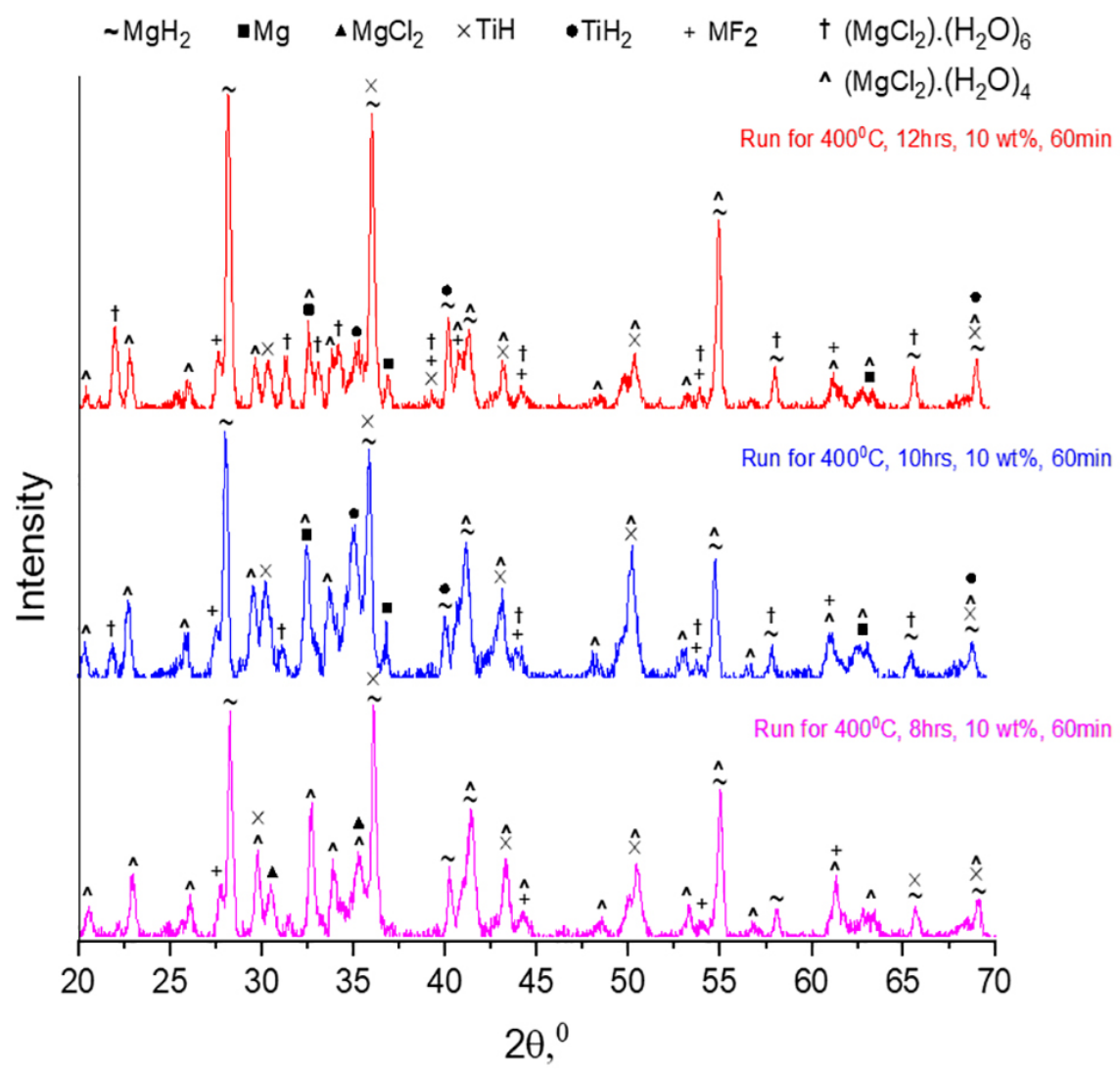

Fig. 6. XRD analysis data for the experiments at 8,10 and $12 \mathrm{hrs}$

\section{Microstructural Characterization}

The morphology and SEM/EDX analysis for the final powder after reaction between $\mathrm{TiCl}_{4}$ and ball milled $\mathrm{MgH}_{2}$ with the conditions listed in table 1, were investigated with provided in Fig. 7 and 9. According to the XRD analysis and the final weight of the powder, the morphology changed with an increase in temperature and reaction time as represented in Fig. 7. Fig. 7(a) shows that the morphology of the final product was agglomerated spherical particles for the experiments with lower temperature and reaction time, such as runs \#4 and \#5. With an increase in the temperature and reaction time, new phase with the angular shaped morphology is appeared such as runs \#6, \#7 and \#18. At low temperatures and reaction times, the main phase is $\mathrm{MgH}_{2}$ which can be seen as spherical shaped 
powders which were partially sintered. With an increase in temperature the major change in the morphology is related to formation of new phase which is related to $\mathrm{TiCl}_{3}$ and $\mathrm{TiH}_{2}$ as shown from Fig. 7(c) to 6(e). It can be seen from Fig. 7(c) to 7(e) that spherical shape particles were almost disappeared and severely agglomerated powders were formed. In addition, due the formation of $\left(\mathrm{MgCl}_{2}\right)\left(\mathrm{H}_{2} \mathrm{O}\right)_{\mathrm{x}}$ phases, the needle shape morphology were detected in the final powders as it is indicated in Fig 7(e).

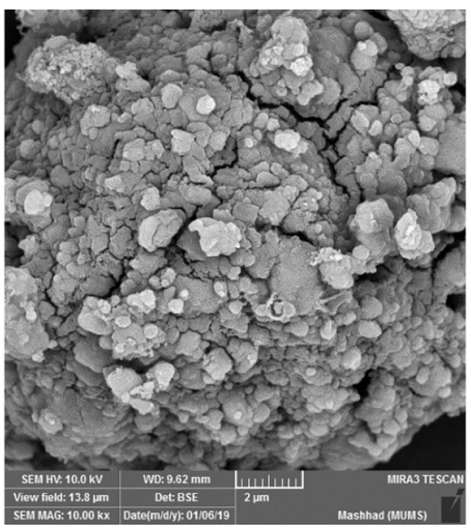

(a)

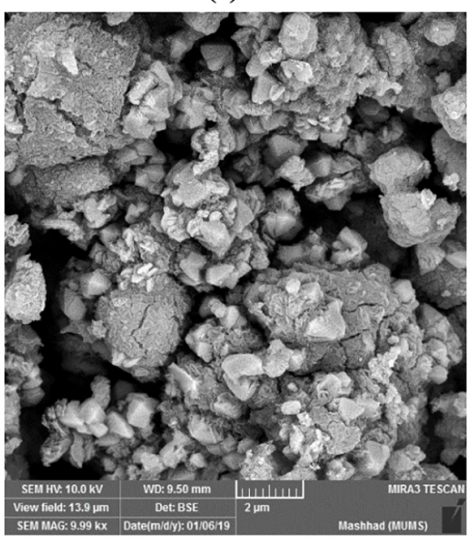

(d)

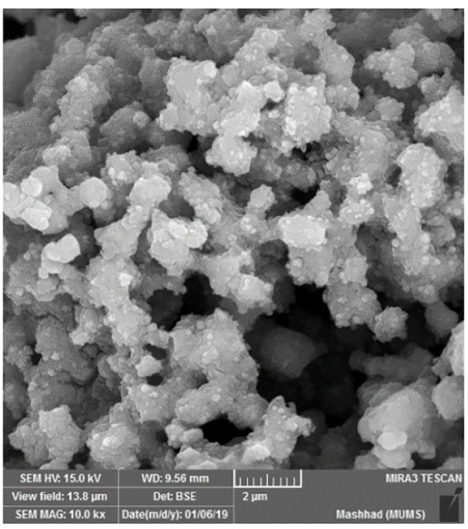

(b)

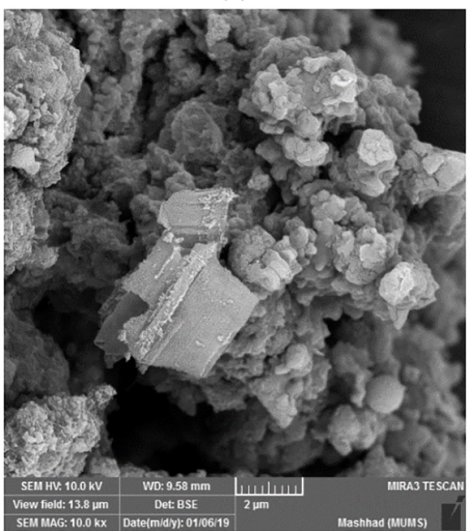

(e)

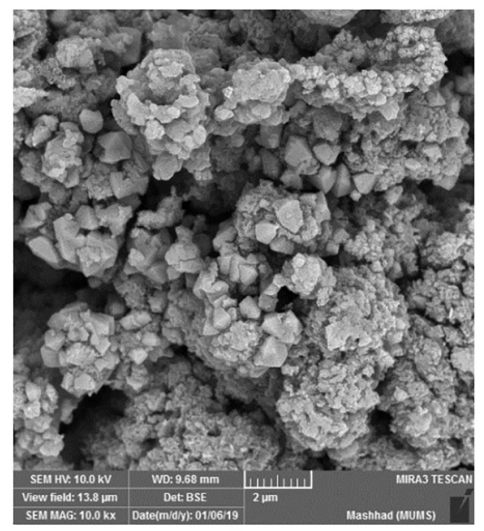

(c)

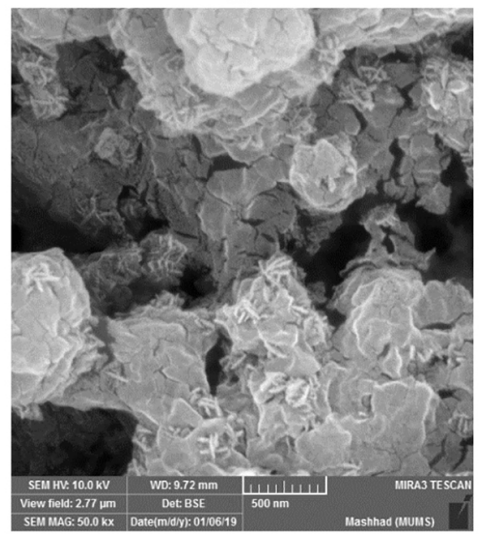

(f)

Fig. 7. SEM image of final powder (a) Run \#4, (b) Run \#5, (c) Run \#6, (d) Run \#7, (e) Run \#18, (f) Run \#13

Fig. 8 shows the SEM/EDX analysis which were confirmed by XRD analysis for the extent of reaction and product phases formed. For the samples reduced at $250^{\circ} \mathrm{C}$, the EDX analysis showed different phases with low $\mathrm{Ti}$ and high $\mathrm{Mg}$ content. On the other hand, with an increase in temperature to $350^{\circ} \mathrm{C}$, the phases with high Ti content were observed. Therefore, with the change in reaction condition more 
Ti was reacted with $\mathrm{MgH}_{2}$. In comparison between samples from run \#9 and run \#18, it was obvious that with the increase in reaction time, the higher Ti content phases were formed during the reaction.
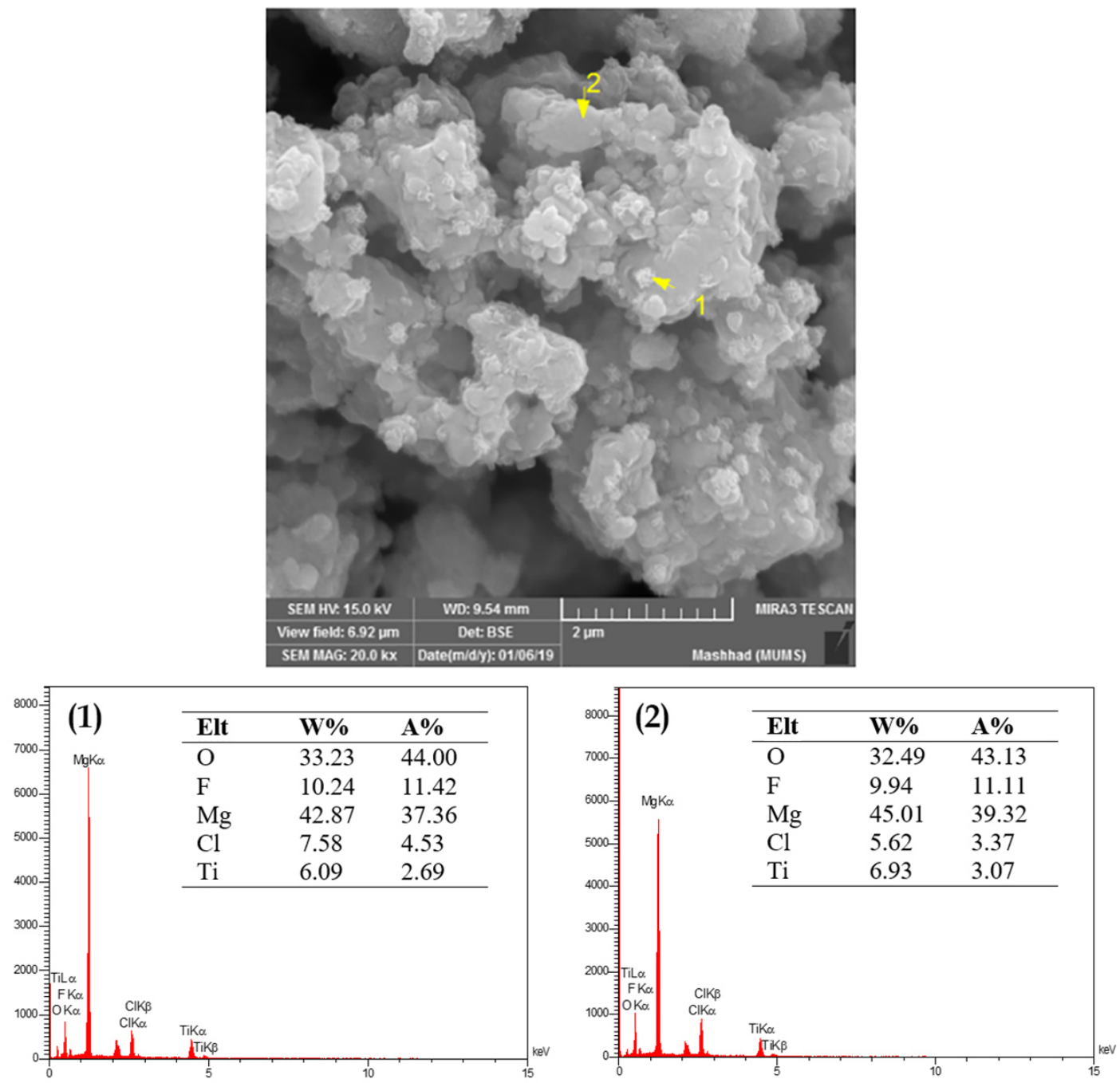

(a) 

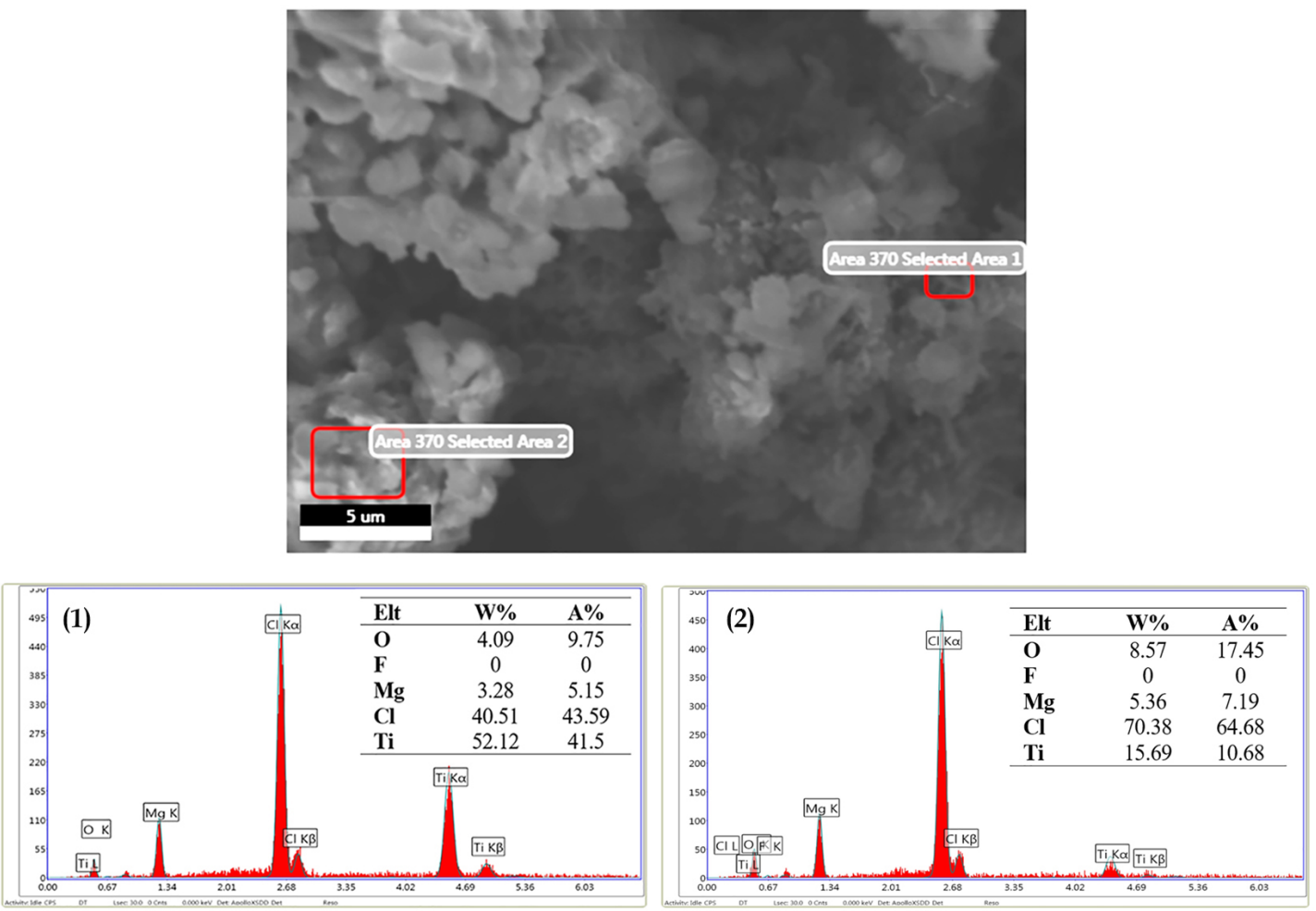

(b) 

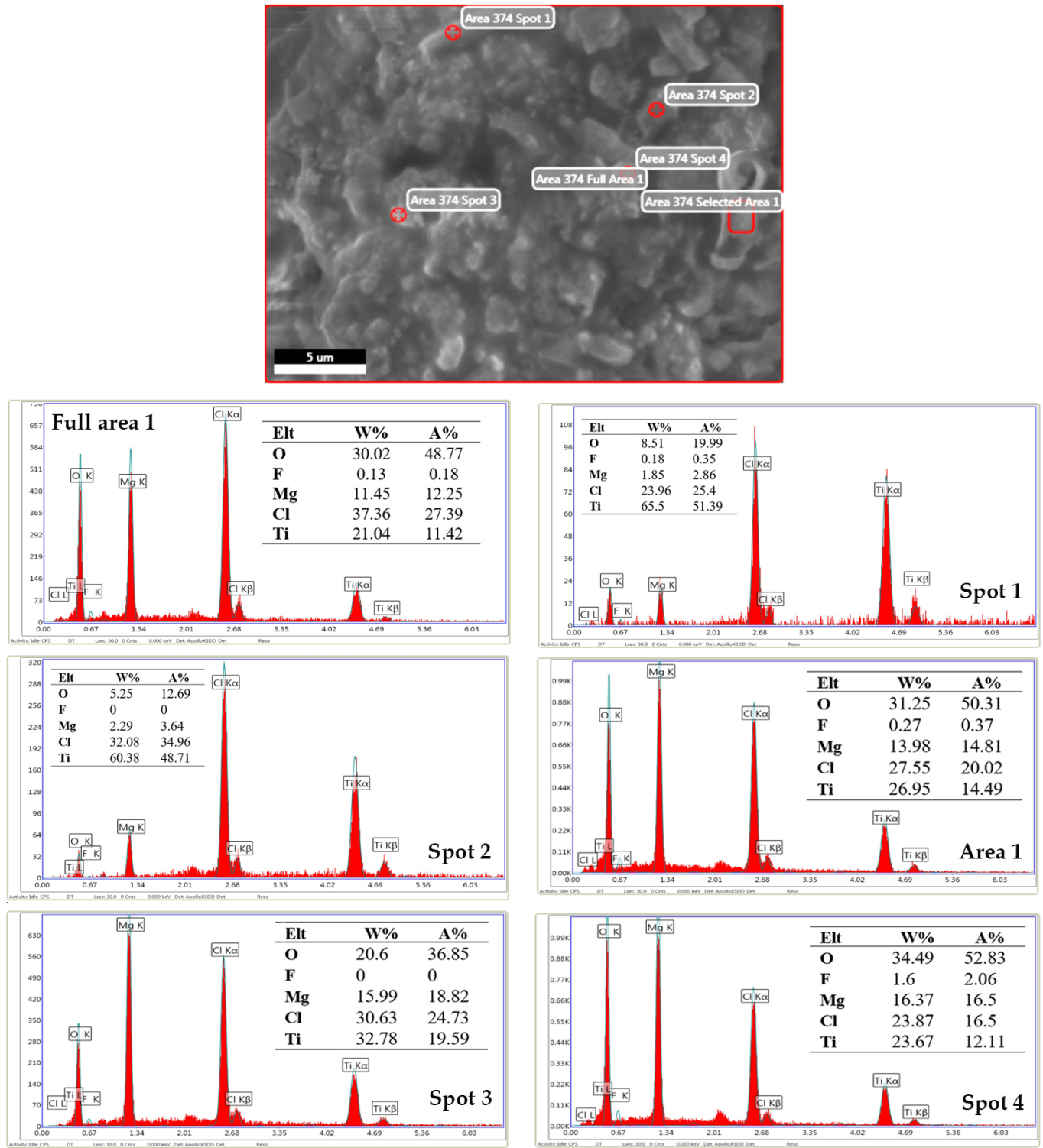

(c)

Fig. 8. EDX analysis of final powder (a) Run \#5, (b) Run \#9, (c) Run \#18

As it was mentioned in the previous section, the XRD results showed that with an increase in reaction time the titanium hydride was formed. Fig. 9 represents the SEM/EDX analyziz for the sample reduced for 10hrs. In comparison with the morphology of the powders in Fig. 7, it is clear that new 
large phase was formed in reaction for $10 \mathrm{hrs}$ and $400^{\circ} \mathrm{C}$. Although the EDX analyziz showed $\mathrm{Mg}, \mathrm{Cl}$ and $\mathrm{O}$ elements in the background, these elements related to the aggolomerated spherical phases in the matrix and the new phase is completely formed from Ti which is related to the formation of titanium hydride.
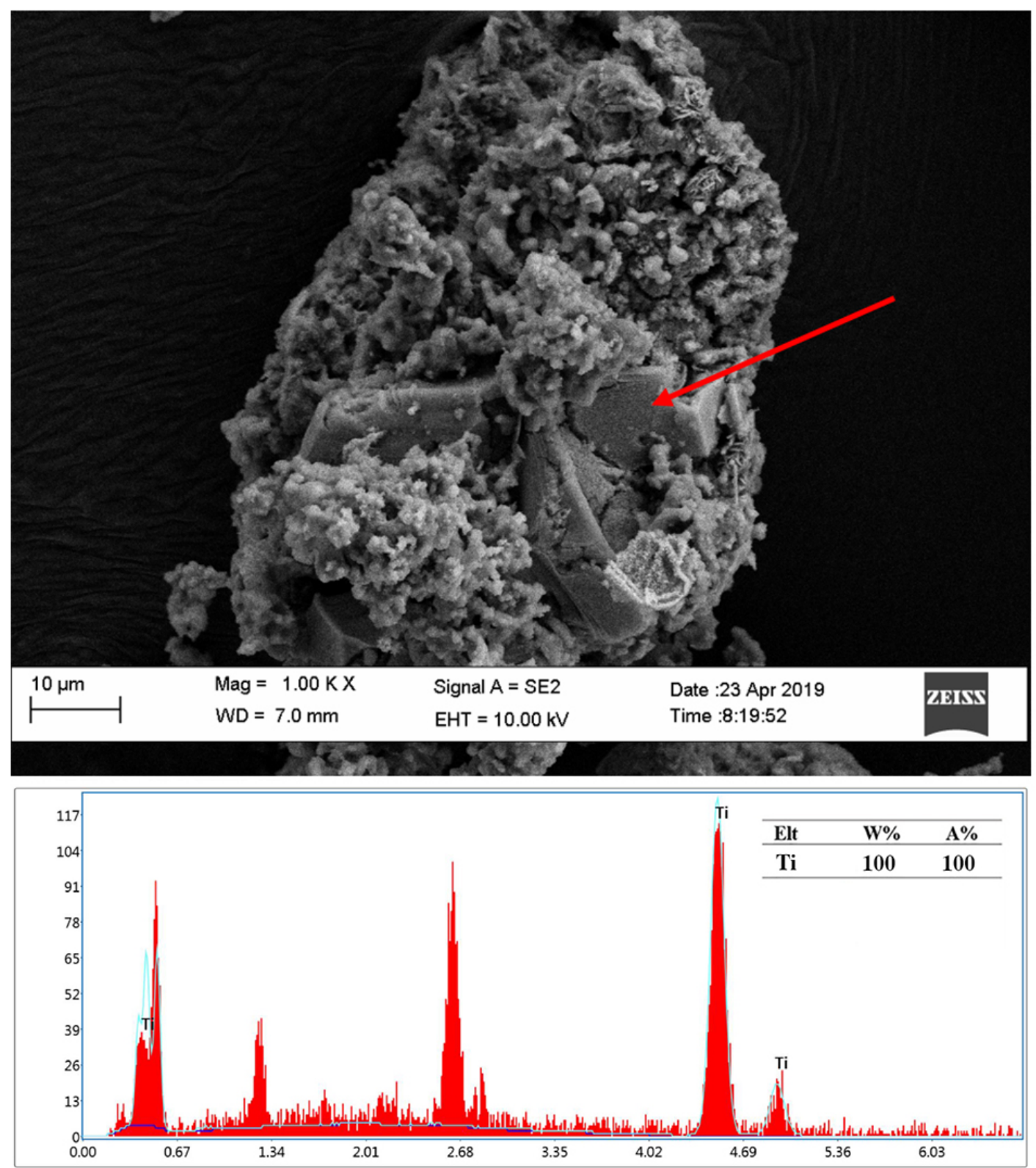
Fig. 9. EDX analysis of final powder for the experiment after $10 \mathrm{hrs}$

The characterization of the final powders confirmed the formation of $\mathrm{TiH}_{2}$ at low temperature through the reaction between $\mathrm{TiCl}_{4}$ and ball milled $\mathrm{MgH}_{2}$. Although, in the reactions at lower reaction times (below 4hrs), the main product phase was $\mathrm{TiCl}_{3}$, in the experiments for longer reaction time above $10 \mathrm{hrs}$ the main phases were $\mathrm{TiH}$ and $\mathrm{TiH}_{2}$. With respect to the chemical compositions of the products, the possible pathway to produce $\mathrm{TiH}_{2}$ with this route was the formation of $\mathrm{TiCl}_{3}$ at the beginning stages of the reduction process and then with an increase in reaction time above $10 \mathrm{hrs}$ and slight increase in temperature up to $400^{\circ} \mathrm{C}$ the reaction between $\mathrm{TiCl}_{3}$ and remaining $\mathrm{MgH}_{2}$ would result in formation of $\mathrm{TiH}_{2}$.

\section{Conclusion}

Experiments have been conducted to synthesize $\mathrm{TiH}_{2}$ from the reaction between ball milled $\mathrm{MgH}_{2}$ and $\mathrm{TiCl}_{4}$ gas in the presence of $\mathrm{H}_{2}$ atmosphere. The investigated parameters were temperature, reaction time, amount of $\mathrm{TiF}_{3}$ and ball milling time. The XRD analyziz of the products showed that the main phase of the reaction at the specified experimental condition in early stages of the reduction process was $\mathrm{TiCl}_{3}$ rather than $\mathrm{TiH}_{2}$. However, with an increase in reaction time above $10 \mathrm{hrs}$, $\mathrm{TiH}$ and $\mathrm{TiH}_{2}$ phases were formed. In addition, it was reported that with increase in the temperature and reaction time, more $\mathrm{TiCl}_{3}$ was formed according to the conditions of run \#10 and \#11. On the other hand, with the increase in reaction time from $2 \mathrm{hrs}$ to $4 \mathrm{hrs}$, $\mathrm{TiH}_{2}$ phases was observable by XRD in run \#18. The $\mathrm{SEM} / \mathrm{EDX}$ characterization of the products indicated that at $250^{\circ} \mathrm{C}$, the main morphology observed was spherical shaped which was related to the unreacted $\mathrm{MgH}_{2}$. However, with an increase in temperature to $350^{\circ} \mathrm{C}$, the new phase of $\mathrm{TiCl}_{3}$ started to appear. Moreover, SEM/EDX analysis showed that at $350^{\circ} \mathrm{C}$ and reaction time for $4 \mathrm{hrs}$ (run \#1), the high Ti content phase was measured which indicated $\mathrm{TiH}_{2}$ and confirmed via XRD analysis. The SEM/EDX analyziz for the reduction process above $10 \mathrm{hrs}$ and temperature of $400^{\circ} \mathrm{C}$ showed the large particles in the final products with $\mathrm{Ti}$ content about $100 \%$ wt which was related to the titanium hydride phases.

\section{Acknowledgements}

The authors wish to thank Universiti Sains Malaysia (USM) and Ministry of Education (MOE) of Malaysia for supporting this work. This research was supported primarily by the following grants; MOHE Fundamental Research Grant Scheme (FRGS) grant \#203/PBAHAN/6071364 and USM Research University Individual (RUI) grant \#1001/PBAHAN/814273. Further support by USM 
research grant was entitled Geran Bridging \#304/PBAHAN/6316116 and Nippon Sheet Glass Research Grant (NSGRG) (\#304/PBA HAN/650360/N120).

\section{$\underline{\text { References }}$}

[1] E.O. Ezugwu, J. Bonney, Y. Yamane, J Mater Process Tech. 134 (2003) 233-253

[2] R.R. Boyer, JOM US. 62 (2010) 21-24

[3] Ervin Tal-Gutelmacher, Dan Eliezer, Mater Trans. 45 (2004) 1594-1600

[4] P.A.T. Olsson, J. Blomqvist, C. Bjerkén, A.R. Massih, Comput. Mater. Sci. 97 (2015) 263-275

[5] G. Crowley, Adv Mater Process. 161 (2003) 25-27

[6] D. J. Fray, Int Mater Rev. 53 (2008) 317-325

[7] C. G. McCracken, C. Motchenbacher, D. P. Barbis, Int J Powder Metall. 46 (2010) 19-26

[8] D.S. Van Vuuren: J. S. Afr. Inst. Min. Metall. 109 (2009) 455-461.

[9] Y. Xia, Z.Z. Fang, T.Y. Zhang, Y. Zhang, P. Sun, Z. Huang: The $13^{\text {th }}$ World Conference on Titanium, California, USA, 2015.

[10] D. S. Van Vuuren: 7th International Heavy Minerals Conference 'What next', The Southern African Institute of Mining and Metallurgy, (2009) 1-7.

[11] M. Qian, F. H. Froes, Titanium Powder Metallurgy: Science, Technology and Applications, first ed., Elsevier, Amsterdam, 2015

[12] Y. Zhang, Z. Z. Fang, Y. Xia, P. Sun, B. V. Devener, M. Free, H. Lefler, S. Zheng, Chem Eng J. 308 (2017) 299-310

[13] S.J. Oosthuizen: J. S. Afr. Inst. Min. Metall. 111 (2011) 199-202

[14] W. Chen, Y. Yamamoto, W.H. Peter, M.B. Clark, S.D. Nunn, J.O. Kiggans, T.R. Muth, C.A. Blue, J.C. Williams and K. Akhtar: J. Alloy. Compd. 541 (2012) 440-447.

[15] C. Doblin, A. Chryss and A. Monch: Key Eng. Mater. 520 (2012) 95-100. 
[16] D.S. van Vuuren: Direct titanium powder production by metallothermic processes, in Titanium Powder Metallurgy: Science, Technology and Applications. 2015. p. 69-93.

[17] Z.Z. Fang, S. Middlemas, J. Guo and P. Fan, J. Am. Chem. Soc. 135 (2013) 18248-18251.

[18] E. Ahmadi, S. A. Rezan, N. Baharun, S. Ramakrishnan, A. Fauzi, G. Zhang, Metall Mater Trans B. 45 (2017) 2354-2366

[19] E. Ahmadi, A. Fauzi, H. Hussin, N. Baharun, K. S. Ariffin, S. A. Rezan, Int J Min Met Mater. 24 (2017) 444-454

[20] E. Ahmadi, Y. Yashima, R. O. Suzuki, S. A. Rezan, Metall Mater Trans B. 49 (2018) 1808-1821

[21] M. R. Ardani, A. S. M. Al Janabi, S. Udayakumar, S. A. Rezan, M. N. A. Fauzi, A. R. Mohamed, H. L. Lee, I. Ibrahim, in: G. Azimi, H. Kim, S. Alam, T. Ouchi, N. R. Neelameggham, A. A. Baba (Eds.), Rare Metal Technology 2019, Springer, Cham, 2019, pp. 131-144

[22] S. Udayakumar, A. Sadaqi, N. Ibrahim, M. N. A. Fauzi, S. Ramakrishnan, S. A. Rezan, JPCS. 1082 (2018) 012003-012009

[23] S. Udayakumar, A. Sadaqi, N. Ibrahim, M. N. A. Fauzi, S. Ramakrishnan, S. A. Rezan, JPCS. 1082 (2018) 012037-012043

[24] Z. Z. Fang, P. Fan, S. Middlemas, J. Guo, Y. Zhang, M. Free, A. Sathyapalan, Y. Xia, U.S. Patent Application No. 14/912846, 2016

[25] V. Duz, M. Matviychuk, A. Klevtsov, V. Moxson, Met Powder Rep. 72 (2016) 30-38

[26] V. Duz, V. S. Moxson, A. G. Klevtsov, V. Sukhoplyuyev, Titanium 2013 Conference, Nevada, USA, 2013

[27] C.R.F. Azevedo, D. Rodrigues, F. Beneduce Neto, J Alloy Compd. 353 (2003) 217-227

[28] O. Ivasishin, V. Moxson, in: M. Qian, F. H. Froes (Eds.), Titanium Powder Metallurgy: Science, Technology and Applications, Elsevier, Amsterdam, 2015, pp 117-148

[29] A. Grzech, U. Lafont, P. C. M. M. Magusin, F. M. Mulder, J. Phys. Chem. C. 116 (2012) 26027-26035

[30] O. Palumbo, F. Trequattrini, F.M. Vitucci, A. Bianchin, A. Paolone, J Alloy Compd. 645 (2014) S239-S241 
[31] A. Roine, "Outokumpu HSC Chemistry, Chemical reaction and equilibrium software with extensive thermochemical database", Finland Outokumpu Research Oy, 2006

[32] L. P. Ma, X. D. Kang, H. B. Dai, Y. Liang, Z. Z. Fang, P. J. Wang, P. Wang, H. M. Cheng, Acta Mater. 57 (2009) 2250-2258

[33] S. J. Gao, L. J. Huang, J Alloy Compd. 293-295 (1999) 412-416

[34] G. J. Kipouros, D. R. Sadoway, J. Light Me. 1 (2001) 111-117

[35] Q. Huang, G. Lu, J. Wang, J. Yu, J Anal Appl Pyrolysis. 91 (2011) 159-164 